\title{
Communicative Gestures in Prelinguistic Periods as Predictors of Later Language Development in Korean Toddlers
}

\author{
Jin Ju Choi ${ }^{\mathrm{a}}$, YoonKyoung Lee ${ }^{\mathrm{b}}$ \\ ${ }^{a}$ Department of Speech-Language Pathology and Audiology, Graduate School of Hallym University, Chuncheon, Korea \\ ${ }^{b}$ Division of Speech and Audiology, Hallym University, Chuncheon, Korea
}

Correspondence: YoonKyoung Lee, $\mathrm{PhD}$ Division of Speech Pathology and Audiology, Hallym University, 1 Hallimdaehak-gil, Chunchon 24252, Korea

Tel: +82-33-248-2219

Fax: +82-33-256-3420

E-mail: ylee@hallym.ac.kr

Received: January 5, 2018

Revised: March 19, 2018

Accepted: March 19, 2018

This work was supported by the Lee Seung Hwan's Scholarship from the Korean Academy of Speech-Language Pathology and Audiology in 2017.

\begin{abstract}
Objectives: The use of communicative gestures in the prelinguistic period is closely related to later language development. This study aimed to examine whether communicative gestures used in the prelinguistic period predict later language development at 24 months of age in Korean toddlers. Methods: The participants were 42 toddlers age 12-18 months who participated in the Korean edition of the Communication and Symbolic Behavior Scales Developmental Profile (CSBS DP) standardization study and also participated in a followup study for tracking language development at 24 months of age. The behavior samples for measuring communicative gestures during the prelinguistic periods were the behavior samples that were collected through the CSBS DP. The total frequency of gestures, the number of gesture types, the frequency of gestures by category, and the frequency of each gesture type were measured. Language ability at 24 months was measured according to receptive language age and expressive language age using SELSI and number of expressive vocabulary words using K M-B CDI. Results: The total frequency of gestures, the frequency of deictic gestures among three gesture categories, and the frequency of pointing gestures among the gesture types in the prelinguistic period predicted the receptive language age, the expressive language age, and the number of expressive vocabulary words at 24 months of age. The frequency of conventional gestures predicted receptive language age as well. Conclusion: The results showed that the communicative gestures, especially the total frequency of communicative gestures, frequency of deictic category gestures, and pointing gestures predicted later language development. We discuss the implications for early identification of toddlers with developmental language delay.
\end{abstract}

Keywords: Toddler, Communicative gestures, Gesture type, Deictic gesture, Pointing
언어이전기는 아직 언어발달이 이루어지지 않아서 주로 몸짓이 나 발성, 시선과 같은 비언어적인 수단을 통해 의사소통을 하는 시 기(Brady, Marquis, Fleming, \& McLean, 2004)로, 이 시기의 비언 어적 수단을 통한 의사소통 발달은 추후 언어를 통한 의사소통 발 달의 기초를 이룬다(Lee \& Lee, 2016). 그 중에서도 특히 언어이전 기의 몸짓 사용은 의사소통 행동 발달의 초기적인 형태로(Bates \& Dick, 2002) 이후의 언어발달과 밀접한 관계가 보고되어 왔다(Lee \& Lee, 2015; Namy, Acredolo, \& Goodwyn, 2000; Rowe \& GoldinMeadow, 2009; Thal, Tobias, \& Morrison, 1991).
몸짓 중에서도 의사소통 의도를 가지고 사용된 몸짓을 의사소 통적 몸짓이라 한다(Lee \& Lee, 2015). 의사소통 몸짓은 언어이전 시기의 영유아들에게 주요 의사소통 수단이 될뿐만 아니라(Lee \& Lee, 2015), 다른 사람의 관심을 얻거나 유지하는 의사소통적인 목 적을 위해 사용되기 때문에 영유아가 언어를 배우는 데 필수적인 요소로 작용한다.

Bates와 Dick (2002)이 영아의 몸짓과 초기 언어발달이 발달적 및 신경학적으로 “가까운 가족(close family)"이라고 표현한 것처 럼, 몸짓은 언어발달의 가장 초기 단계에 중요한 역할을 한다. Mor- 
ford와 Goldin-Meadow (1992)는 영유아 시기의 몸짓이 구어와 중 복적으로 사용될 뿐 아니라 구어를 대신할 수 있다고 보고하였으 며, 아주 어린 영유아 시기부터 몸짓은 구어의 산출과 이해를 통합 하는 시스템을 자연스럽게 형성한다고 하였다. 이러한 몸짓 사용은 언어 상징을 발달시키며, 이는 수용언어와 표현언어 영역 모두에서 언어능력을 보충하고 명확하게 하여 언어발달에 대한 발판을 제공 해준다(Capirci, Iverson, Pizzuto, \& Volterra, 1996).

많은 선행연구들은 영아의 의사소통적 몸짓 사용 빈도가 이후의 언어발달을 예측해준다고 보고하였다(Capirci et al., 1996; Iverson \& Goldin-Meadow, 2005; Rowe \& Goldin-Meadow, 2009). 이탈리 아 영아들을 대상으로 몸짓과 표현언어 발달을 종단적으로 연구한 Capirci 등(1996)은 16 개월의 전체 몸짓 빈도와 몸짓과 단어조합이 20 개월의 표현언어 산출과 유의한 상관이 있다고 보고하였으며, Rowe, Özçalışkan과 Goldin-Meadow (2008)는 14개월에 몸짓 사 용 빈도가 이후 42 개월의 언어발달을 예측하였다고 보고하였다.

몸짓 빈도만이 아니라 영아들이 사용한 몸짓 유형도 언어발달과 관련이 된다. Bates, Thal, Whitesell, Fenson과 Oakes (1989)는 12-16 개월 영유아들을 대상으로 64 개의 몸짓 목록(inventory)과 이해 및 표현어휘를 양육자에게 평가하게 한 결과, 몸짓 유형 빈도가 이 해와 표현어휘 수와 정적 상관관계가 있었다고 보고하였다. 18 개월 의 몸짓 사용과 42 개월의 언어능력과의 관계를 종단적으로 살펴본 Rowe와 Goldin-Meadow (2009)도 18개월에 나타낸 몸짓 유형 수 가 42 개월의 이해 어휘능력을 예측할 수 있는 것으로 보고하였으 며 Rowe 등(2008)도 14개월에 몸짓 사용 빈도와 더불어 다양한 몸 짓을 사용한 영아가 그렇지 않았던 영유아에 비해 42 개월의 이해 어휘 크기가 더 컸다고 보고하였다.

몸짓 유형 중에서는 특히 가리키기 몸짓이 언어발달과 밀접하게 관련된다는 사실이 보고되어 왔다(Crais, Douglas, \& Campbell, 2004; Harris, Barlow-Brown, \& Chasin, 1995). Camaioni, Castelli, Longobardi와 Volterra (1991)는 언어 표현이 시작되기 전 시기인 12 개월의 가리키기 빈도가 20 개월의 어휘 크기와 상관이 있다고 보고하였으며, Harris 등(1995)도 평균 연령이 10 개월인 6명의 영아 를 대상으로 가리키기의 산출 시기와 문맥적으로 사물의 이름을 이해하기 시작하는 시기 간에 유의한 상관관계가 있었다고 보고하 였다. Butterworth와 Morissette (1996)도 영아들이 대체로 11개월 에 가리키기를 사용하였으며, 이는 이후 14 개월의 몸짓 수와 소리 이해 수를 예측하여 가리키기의 시작 시기가 언어 습득의 다리 (bridge)가 될 수있다고 하였다.

몸짓은 영아가 속한 문화권에 따라 달라질 수 있으며, 언어발달 역시 사용 언어에 따라 달라질 수 있다. 때문에 외국 영유아들에게
서 밝혀진 연구결과들을 우리나라 영유아에게도 동일하게 적용할 수 있는지 국내 여러 학자들에 의해서도 반복적으로 연구되었다 (Chang, Choi, \& Kim, 2005; Kim \& Kim, 2006; Lee \& Lee, 2015; Lee, Jeon, \& Lee, 2014; Shin \& Kim, 2016). 7-24개월 영아들을 대상 으로 한 몸짓 사용과 언어발달 간의 관계를 살펴본 Kim과 Kim (2006)은 몸짓의 전체 빈도가 많을수록 이해와 표현어휘가 많았다 고 보고하였으며, 몸짓 유형 중에서는 지시적 몸짓 빈도가 이해어 휘와, 표상적 몸짓 빈도는 표현 및 이해어휘와 정적 상관을 보였다 고 보고하였다. 10-18개월의 영아의 몸짓 사용과 이후 22-30개월의 언어발달 간의 관계를 종단적으로 살펴본 Shin과 Kim (2016) 역시 전체 몸짓 빈도와 유형 수가 표현 및 이해어휘 수와 유의한 상관이 있었다고 보고하였으나 몸짓 유형에 따라서는 관습적 몸짓 빈도가 이해 어휘를, 표상적 몸짓 빈도가 표현어휘를 설명하였다고 하여 약간 다른 결과를 보고하였다. 전형적 발달 영아를 대상으로 한 앞 선 연구들과 다르게 $18-24$ 개월의 언어발달지체 영아와 일반 영아 의 의사소통 몸짓을 비교한 Lee와 Lee (2015)도 언어발달지체 영유 아들은 또래 일반 영유아들에 비해 유의하게 전체 몸짓 빈도가 적 었다고 보고하여 언어발달과 몸짓 발달이 관련될 수 있음을 보고 하였다.

앞서 보고한 연구들은 방법론적 차이에도 불구하고 모두 의사 소통 몸짓이 언어발달과 관련된다는 사실을 일관되게 보고하여 몸 짓 사용과 언어발달 간의 관계에 중요한 시사점을 준다. 반면, 몸짓 의 유형 측면에서는 다른 결과들을 보고하였는데, 이는 연구들이 갖는 여러 방법론적 차이, 그 중에서도 연구 대상 영유아들의 연령 요인을 고려할 수 있다. 즉 Kim과 Kim (2006)은 7-24개월의 영아 를 대상으로 하였는데, 이 시기는 아직 언어발달이 시작되기 전에 서부터 언어를 주된 의사소통 수단으로 사용하는 다양한 언어발 달 수준의 영아들이 포함되며(Lee \& Lee, 2015, 2016), 몸짓 발달 수 준 또한 다양한 시기라 할 수 있다(Crais et al., 2004; Lee \& Lee, 2015). 몸짓과 언어발달 간의 관계를 종단적으로 살펴본 Shin과 $\operatorname{Kim}$ (2016)도 Kim과 Kim (2006)보다는 연령폭이 작지만 마찬가 지로 10-18개월에 의사소통 몸짓을 측정하고 이후 22-30개월 사이 에 언어능력을 측정하여 다양한 의사소통 몸짓이나 언어발달 수 준의 영아들이 포함되었다는 점에서는 유사하다. 초기 의사소통 몸짓 사용과 이후 언어발달에 미치는 영향은 영아들의 몸짓 발달 수준이나 이후 언어발달 시기에 따라 달라질 수 있다. 때문에 의사 소통 몸짓이나 언어발달 수준이 다양한 영아들을 대상으로 한 연 구를 토대로 의사소통 몸짓 발달이 이후 언어발달에 어떠한 영향 을 갖는지 설명하는 데에는 제한이 있을 수 있다.

본 연구는 선행연구들이 가질 수 있는 제한점을 보완하여, 의사 
소통 발달 수준이 유사한 시기에 몸짓발달을 측정하고, 동일한 시 기에 언어발달을 측정하여 그 관계를 확인해보고자 하였다. 이는 이전에 보고된 결과를 확인하고 해석하는 데 도움이 되리라 생각 한다. 언어이전기의 의사소통 몸짓과 언어발달 간의 관계를 살펴보 는 것은 이후 언어발달을 예측하는 데 유용할 뿐만 아니라 언어발 달에 어려움을 가진 영유아를 조기에 발견하고 지연을 예측하는 데 시사점을 줄수 있을 것이다.

\section{연구방법}

\section{연구참가자}

본 연구의 참가자는 생활연령이 24 개월인 전형적 발달을 보이는 영아 42 명이었다. 연구 참여 영아는 12-18개월 사이에 한국판 의사 소통 및 상징행동 평가척도(K-CSBS DP) 표준화 연구에 참여한 영 아로, 아직 표현어휘가 10 개 미만으로 비언어적 의사소통 수단을 주된 의사소통 수단으로 하며 보호자가 이후 24 개월의 언어발달 을 추적하는 연구에 동의한 영아들이었다. 추적 시기를 24 개월로 한 이유는 이 시기에 이르면 대부분의 영아들이 언어를 통한 의사 소통이 활발해지기 시작하는 시기로(Lee \& Lee, 2016; Wetherby, Cain, Yonclas, \& Warker, 1988) 의사소통적 몸짓 사용이 초기 언어 습득에 미치는 영향을 살펴보고자 하는 본 연구의 목적에 적합한 시기로 판단하였기 때문이었다.

영아들의 언어이전기 의사소통적 몸짓 사용을 측정한 시기의 평균 월령은 15.17 개월이었다. 언어발달을 평가하기 위한 추적연구 는 모두 정확히 24 개월이 되는 시점에 실시하여 언어발달 평가 시 기의 평균월령은 24 개월이었다. 두 시기 모두 영아선별·교육진단검 사(DEP; Jang, Seo, \& Ha, 2011)를 사용하여 발달이 전형적인지를 확인하였다. 본 연구에 참여한 참가자 정보는 Table 1과 같다.

\section{자료수집 도구}

의사소통 몸짓은 CSBS DP의 한국판 표준화 과정에서 얻어진 행 동평가 표본을 사용하여 측정하였으며, 언어능력은 영유아언어발 달검사(SELSI; Kim, Kim, Yoon, \& Kim, 2003)와 한국판 맥아더-베

Table 1. Participants' information

\begin{tabular}{llc}
\hline & \multicolumn{1}{c}{ 1st test } & 2nd test \\
\hline Chronological age (mo) & $15.17(2.16)$ & $24(.00)$ \\
DEP total score (\%ile) & $75.72(16.72)$ & $78.27(14.02)$ \\
\hline
\end{tabular}

Values are presented as mean (SD).

$\mathrm{DEP}=$ developmental assessment for the early intervention program planning (Jang, Seo, \& Ha, 2011).
이츠 의사소통발달검사(K M-B CDI; Pae \& Kwak, 2011)를 사용하 여측정하였다.

CSBS DP는 6 개월에서 2세 정도 영아의 의사소통 및 초기 상징 행동을 평가하기 위하여 고안된 검사도구로 언어이전이나 초기 언 어습득 단계에 있는 영아의 의사소통 행동을 평가하는 데 효과적 이어서 교육 및 임상현장에서는 물론 영아 연구에 폭넓게 활용되 고 있다(Lee \& Lee, 2014; Lee \& Lee, 2017; Jeon, Lee, \& Lee, 2013). 본 연구에서는 CSBS DP 행동평가의 4 가지의 구조화된 의사소통 행동 유도 절차(태엽장난감, 비누방울, 풍선불기, 병속 과자)와 소 꿉놀이 및 책 읽기 절차를 통해 얻어진 표본을 활용하였다. 소꿉놀 이 및 책 읽기 표본의 길이는 모든 영아들에게 5 분으로 동일하게 하였다.

SELSI는 5-36개월 사이의 영유아를 대상으로 영유아의 전반적 인 언어발달을 평가하고 언어발달에서 지연을 보이는 아동을 조기 에 선별하기 위한 목적으로 개발된 검사도구이다. 검사 영역은 수 용언어와 표현언어 영역으로 나뉘며 각 영역은 의미, 음운, 구문, 화 용 영역으로 세분화되어 있다. 본 연구에서는 양육자가 각 문항에 직접 답하는 형식으로 실시하였다. K M-B CDI는 Pae와 Kwak (2011) 이 Fenson 등(1996)의 연구를 한국판으로 표준화한 것으로 8-36개 월 사이의 영유아의 어휘 사용력, 제스처와 놀이, 문법 수준을 평가 한다. 주 양육자가 제시된 체크리스트를 보고 체크하는 형식으로 실시되며 영아용(8-17개월)은 이해와 표현어휘 및 놀이 제스처 등 을, 유아용(18-36개월)은 표현어휘와 문법 사용력을 평가한다. 본 연구에서는 유아용을 사용하여 표현어휘를 측정하였다.

\section{자료수집 절차}

먼저 언어발달 추적연구 참여에 동의하였던 영아의 보호자에게 영아가 24개월이 되기 1-2개월 전에 연락하여 검사 일시와 장소를 조정하였으며, 정해진 날짜에 연구자가 대상 영아의 가정을 방문하 여 실시하였다. 연구자는 양육자에게 연구 목적과 절차, 내용을 설 명하고 연구 참여에 대한 동의를 얻은 후 검사를 실시하였다. 부모 보고 형식의 검사인 SELSI와 K M-B CDI의 작성방법을 안내한 후 양육자가 직접 답하게 하였다. 검사를 응답하는 중에 양육자가 문 항의 내용을 충분히 이해하지 못한 경우 연구자가 옆에서 설명을 해 주었다. 검사 응답을 완료한 후에는 빠진 문항이 있는지 검토하고, 답하지 않은 문항이 있는 경우는 양육자에게 확인 질문하여 모든 문항을 빠트리지 않고 답하도록 하였다. 검사 일정의 조율이 어렵거 나 개별적인 이유로 연구자가 직접 방문이 불가능하였던 소수의 참 가자에게는 우편으로 검사지를 발송하였다. 양육자가 검사에 답변 하는 데 어려움이 없도록 전화를 통해 도움을 제공하였다. 


\section{자료분석 및 측정}

의사소통 몸짓은 CSBS DP 행동표본에서 전체 의사소통적 몸짓 사용 빈도, 몸짓의 유형 수, 몸짓 범주별(지시적, 관습적, 표상적) 사 용 빈도, 몸짓 유형별 빈도를 측정하였다. 몸짓 분석을 위한 기준은 Iverson과 Goldin-Meadow (2005)의 분류 체계를 토대로 한 Lee와 Lee (2015)의 조작적 정의를 따랐으며, 이는 Appendix 1에 제시하 였다.

언어능력은 SELSI의 수용언어연령과 표현언어연령, 그리고 K $\mathrm{M}-\mathrm{B} \mathrm{CDI}$ 의 표현어휘 수로 측정하였다.

\section{신뢰도}

의사소통적 몸짓 분석 및 측정에 대한 신뢰도를 측정하였다. 신 뢰도 평가자로 영유아 의도적 의사소통행동 분석 경험이 많은 언 어병리학전공 석사과정생이 참여하였다. 평가자에게는 종속측정 치에 대한 조작적 정의를 자세히 설명하였으며, 두 영아 행동 표본 으로 분석 훈련을 실시하였다. 훈련 과정에서 불일치한 경우에는 토론을 거쳐 최대한 일치된 기준을 가질 수 있도록 하였다. 훈련 과정을 통해 연구자와 평가자 간의 분석 일치도가 $90 \%$ 이상이 되 었을 때 전체 연구참가자 자료의 $20 \%$ 인 8 명의 자료를 임의로 추출 하여 독립적으로 분석하였으며, 연구자와 평가자 간의 일치도로 신뢰도를 측정하였다. 신뢰도 측정 결과, 전체 의사소통적 몸짓 사 용 빈도는 97\%, 유형 수에 대한 신뢰도는 96.5\%, 몸짓 범주별 사 용 빈도는 $93.8 \%$, 몸짓 유형별 사용 빈도는 $94.1 \%$ 로 일치도가 측 정되었다.

\section{자료의 통계처리}

측정된 자료는 IBM SPSS Statistics version 22를 이용하여 통계 처리 하였으며, 단계별 회귀분석을 통해 의사소통 몸짓이 언어발달 을 예측해주는지를 분석하였다.

Table 2. Regression analysis: total frequency of gesture and number of gesture type as a predictor of later language development

\begin{tabular}{lcccc}
\hline $\begin{array}{l}\text { Independent } \\
\text { variable }\end{array}$ & $\begin{array}{c}\text { Dependent } \\
\text { variable }\end{array}$ & $\beta$ & Adj R & $F$ \\
\hline Total frequency of gestures & $\mathrm{RLA}^{\mathrm{a}}$ & .560 & .296 & $18.269^{* * *}$ \\
& $\mathrm{ELA}^{\mathrm{a}}$ & .526 & .259 & $15.302^{* * *}$ \\
& $\mathrm{EV}^{\mathrm{b}}$ & .364 & .111 & $6.096^{* *}$ \\
\hline
\end{tabular}

$\mathrm{RLA}=$ receptive language age; $E L A=$ expressive language age. a Sequenced Language Scale for Infants (Kim, Kim, Yoon, \& Kim, 2003).

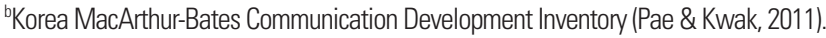
${ }^{* *} p<.01,{ }^{* * *} p<.001$.

\section{연구결과}

\section{전체 몸짓 사용 빈도와 언어발달}

전체 의사소통적 몸짓 사용 빈도, 유형수와 24 개월 언어발달 간의 상관분석을 실시한 결과, 전체 의사소통적 몸짓 사용 빈도는 SELSI 의 수용언어연령 $(r=.560, p<.01)$, 표현언어연령 $(r=.526, p<.01), \mathrm{K}$ $\mathrm{M}-\mathrm{B} \mathrm{CDI}$ 표현어휘 수 $(r=.364, p<.01)$ 모두 유의한 상관이 있었다. 유형 수는 수용언어연령 $(r=.349, p<.05)$, 표현언어연령 $(r=.365$, $p<.05)$ 과 유의한 상관을 보였으며 표현어휘 수와는 유의한 상관은 없었다. 유의한 상관을 보인 전체 몸짓 빈도와 유형수에 대하여 단 계적 회귀분석을 실시한 결과, 전체 의사소통적 몸짓 사용 빈도가 수용언어연령을 $29.6 \%(F=18.269, p<.001)$, 표현언어연령을 $25.9 \%$ $(F=15.302, p<.001)$ 로 표현어휘 수를 $11.1 \%(F=6.096, p<.05)$ 설 명하였다(Table 2).

\section{범주별 몸짓 빈도와 언어발달}

범주별 몸짓 빈도와 24 개월 언어발달 간의 상관분석을 실시한 결과, 지시적 몸짓은 SELSI의 수용언어연령 $(r=.438, p<.01)$ 및 표 현언어연령 $(r=.417, p<.01), \mathrm{K} \mathrm{M}-\mathrm{B}$ CDI의 표현어휘 수 $(r=.423$, $p<.01)$ 와 유의한 상관이 있었고, 표상적 몸짓은 수용언어연령, 표 현언어연령, 표현어휘 수와 유의한 상관은 없었다. 관습적 몸짓은 SELSI의 수용언어연령 $(r=.361, p<.05)$ 과 유의한 상관을 보였고, 표현언어연령과 표현어휘 수와는 상관이 없었다. 유의한 상관을 보 인 지시적 몸짓과 관습적 몸짓에 대하여 단계적 회귀분석을 실시한 결과, 지시적 몸짓 빈도가 수용언어연령을 $17.2 \%(F=9.496, p<.01)$, 표현언어연령을 $15.3 \%(F=8.430, p<.01)$, 표현어휘수를 $15.9 \%$ $(F=8.729, p<.01)$ 설명하였다. 관습적 몸짓 빈도는 지시적 몸짓과 더불어 수용언어연령을 $30.8 \%(F=10.137, p<.001)$ 설명력을 가져 추가적으로 $13.6 \%$ 를 설명하였다(Table 3).

Table 3. Regression analysis: frequency of gesture by category as a predictor of later language development

\begin{tabular}{lcccc}
\hline $\begin{array}{l}\text { Independent } \\
\text { variable }\end{array}$ & $\begin{array}{c}\text { Dependent } \\
\text { variable }\end{array}$ & $\beta$ & $\operatorname{Adj}^{2}$ & $F$ \\
\hline Frequency of deictic gestures & $\mathrm{RLA}^{\mathrm{a}}$ & .438 & .172 & $9.496^{* *}$ \\
$\begin{array}{l}\text { Frequency of deictic gestures }+ \\
\quad\end{array}$ & & .461 & .308 & $10.137^{* * *}$ \\
$\quad$ frequency of conventional gestures & & .388 & & \\
Frequency of deictic gestures & $\mathrm{ELA}^{\mathrm{a}}$ & .417 & .153 & $8.430^{* *}$ \\
& $\mathrm{EV}^{\mathrm{b}}$ & .422 & .159 & $8.729^{* *}$ \\
\hline
\end{tabular}

$\mathrm{RLA}=$ receptive language age; $E L A=$ expressive language age. aSequenced Language Scale for Infants (Kim, Kim, Yoon, \& Kim, 2003).

${ }^{b}$ Korea MacArthur-Bates Communication Development Inventory (Pae \& Kwak, 2011). ${ }^{* *} p<.01,{ }^{* * *} p<.001$. 
Table 4. Regression analysis: frequency of each gesture as a predictor of later language development

\begin{tabular}{lcccc}
\hline $\begin{array}{l}\text { Independent } \\
\text { variable }\end{array}$ & $\begin{array}{c}\text { Dependent } \\
\text { variable }\end{array}$ & $\beta$ & Adj $R^{2}$ & $F$ \\
\hline Frequency of pointing & $\mathrm{RLA}^{\mathrm{a}}$ & .515 & .247 & $14.437^{* * *}$ \\
& $\mathrm{ELA}^{\mathrm{a}}$ & .460 & .192 & $10.726^{* *}$ \\
& $\mathrm{EV}^{\mathrm{b}}$ & .550 & .285 & $17.356^{* * *}$ \\
\hline
\end{tabular}

$\mathrm{RLA}=$ receptive language age; $E L A=$ expressive language age. a Sequenced Language Scale for Infants (Kim, Kim, Yoon, \& Kim, 2003).

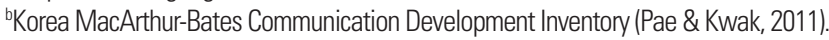
${ }^{* *} p<.01,{ }^{* * *} p<.001$.

\section{몸짓 유형별 빈도와 언어발달}

세부 몸짓별 사용 빈도와 24 개월의 언어점수 간의 상관관계 결 과, 지시적 몸짓의 가리키기만이 SELSI의 수용언어연령 $(r=.515$, $p<.01)$, 표현언어연령 $(r=.460, p<.01)$ 과 $\mathrm{K} \mathrm{M}-\mathrm{B} \mathrm{CDI}$ 의 표현어휘 수 $(r=.550, p<.01)$ 와 유의한 상관관계가 있었다. 회귀분석 결과 독 립변인으로 투입한 가리키기 빈도가 SELSI의 수용언어연령을 $24.7 \%$ $(F=14.437 p<.001)$, 표현언어연령을 $19.2 \%(F=10.726, p<.01), \mathrm{K}$ M-B CDI의 표현어휘 수를 $28.5 \%(F=17.356, p<.001)$ 설명하였다 (Table 4).

\section{논의 및 결론}

본 연구는 언어이전기의 의사소통 몸짓 사용이 이후 언어발달에 미치는 영향을 종단적 연구를 통해 살펴보는 것을 목적으로 하였 으며, 이를 위하여 아직 비언어적 의사소통 수단이 주된 의사소통 수단인 12-18개월에 행동 표본을 수집하여 의사소통 몸짓을 측정 하고, 언어가 본격적인 의사소통 수단으로 자리 잡는 24 개월에 언 어능력을 측정하여 그 영향력을 살펴보았다. 의사소통 몸짓은 선 행연구에서 반복적으로 측정되어 온 전체 의사소통 몸짓 빈도와 유형수, 그리고 몸짓 범주별 빈도와 개별 몸짓 빈도를 측정하였다. 각각에 대한 논의는 다음과 같다.

먼저 전체 의사소통적 몸짓 사용 빈도 및 유형 수 중에서는 전체 의사소통적 몸짓 빈도만 24 개월의 수용언어연령, 표현언어연령, 표 현어휘 수를 설명하였다. 의사소통 몸짓 빈도가 이후의 언어발달 을 설명한다는 사실은 여러 선행연구들에서 보고된 바 있으며(Capirci et al., 1996; Iverson \& Goldin-Meadow, 2005; Rowe \& Goldin-Meadow, 2009) 국내 영아를 대상으로 한 연구에서도 보고된 바 있다(Kim \& Kim, 2006; Shin \& Kim, 2016). 본 연구는 언어이전기 의 의사소통적 몸짓을 예측해 주는 주요 요인임을 확인하였다. 발 달장애 영유아를 대상으로 몸짓과 언어발달 간의 관계를 살펴본
Calandrella와 Wilcox (2000)나 말 늦은 영아들을 추적연구한 Thal 등(1991)도 언어이전기의 몸짓 발달이 이후 언어발달을 예측 해주는 주요 요인임을 제시한 바 있다. 이러한 결과는 언어이전기에 있는 전형적 발달 영아는 물론 언어발달장애 영아들의 이후 언어 발달을 예측할 때 의사소통적 몸짓 사용 빈도가 주요한 요인이 될 수 있음을 시사한다.

반면, 몸짓 유형 수는 이후의 언어발달을 유의하게 설명하지 못 하는 것으로 나타났는데, 이는 둘 간의 관계를 보고한 Bates 등 (1989)이나 Rowe 등(2008)과는 다른 결과이다. 이러한 차이는 선행 연구와 본 연구 간의 방법론적 차이로 고려해 볼 수 있다. Bates 등 (1989)은 부모에서 총 64개의 목록을 제시하여 유형 수를 측정한 반면, 본 연구는 행동 표본을 분석해서 측정한 총 14 가지 유형 수만 을 측정하였다. Rowe 등(2008)은 본 연구와 마찬가지로 행동 표본 을 분석하였으나 언어를 종단적으로 측정한 시점이 42 개월로 본 연구와 차이가 있었다. 이를 토대로 보았을 때 몸짓 유형 수와 언어 발달 간의 관계는 몸짓 유형을 측정하는 방법이나 몸짓 사용과 언 어발달 관계가 측정하는 방법이나 언어발달을 측정하는 시기에 따 라 달라질 수 있음을 시사한다.

몸짓 유형을 범주로 나누어 언어발달에 미치는 영향을 살펴본 결과에서는 지시적 범주의 빈도가 수용언어연령, 표현언어연령, 표 현어휘 수를 설명하였으며, 관습적 몸짓도 수용언어연령을 설명하 는 것으로 나타났다. 국내 영아를 대상으로 한 연구에서 7-24개월 영아를 대상으로 한 Kim과 $\operatorname{Kim}$ (2006)은 지시적 몸짓 빈도가 이 해어휘와, 표상적 몸짓 빈도는 표현 및 이해어휘와 정적 상관을 보 였다고 보고한 반면, $10-18$ 개월의 영아의 몸짓 사용과 이후 22-30개 월의 언어발달 간의 관계를 종단적으로 살펴본 Shin과 Kim (2016) 은 관습적 몸짓 빈도가 이해어휘를, 표상적 몸짓 빈도가 표현어휘 를 설명하였다고 하여 약간 다른 결과를 보고한 바 있다. 본 연구는 지시적 몸짓이 수용언어는 물론 표현언어, 표현어휘 수와 관련되는 것으로 나타나 선행연구와는 다른 결과를 보였다. 앞서 서론 부분 에서 선행연구가 비교적 몸짓이나 언어발달 시기가 다양한 영아들 을 대상으로 하여 발달 시기에 따른 영향을 배제하지 못하였음을 서술한 바 있다. 본 연구는 언어이전기에 몸짓을 측정하고, 언어가 본격적인 의사소통 수단으로 자리 잡는 24 개월에 언어발달을 측정 하여 영아들이 각기 다른 발달 시기에 해당하여 가질 수 있는 문제 를 최대한 통제하여 살펴보았다. 따라서 언어이전기 몸짓과 24개월 시기에 국한하여 몸짓과 24 개월 시점의 언어발달 간의 관계를 설명 할 때에는 보다 의미 있게 해석해도 좋을 듯 하다. 그러나 세 연구가 갖는 방법론적 차이도 존재하므로 추후 반복 연구를 통한 확인이 요구된다. 
Jin Ju Choi, et al. • Communicative Gestures as Predictors of Later Language Development

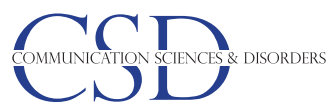

마지막으로 개별 몸짓별 빈도에서는 ‘손가락으로 가리키기’만이 수용언어연령, 표현언어연령, 표현어휘 수를 예측하였다. 언어이전 기의 가리키기가 언어발달에 매우 중요한 의미를 갖는다는 점은 여 러 선행연구들에서 보고되었다(Butterworth \& Morissette, 1996; Camaioni et al., 1991; Iverson \& Goldin-Meadow, 2005; Özçalıskan \& Goldin-Meadow, 2006). 가리키기는 주요한 상호작용 방식인 동 시주의(joint attention) 상황에서 자주 나타나는데, 영아가 사물을 가리키면 양육자가 언어표현으로 바꾸어 말해주고, 이러한 과정을 통해서 해당 표현을 학습하게 된다(Goldin-Meadow, Goodrich, Sauer, \& Iverson, 2007). 따라서 가리키기를 빈번하게 사용하는 영 유아는 타인으로부터 구어적 반응을 이끌어내고, 이를 통해 궁극 적으로 언어발달에 긍정적 영향을 가질 수 있게 된다. 특히 본 연구 에서 개별 몸짓 사용 빈도 중 가장 높은 빈도로 나타난 것은 '주기' 몸짓이었으며, 가리키기 몸짓은 상대적으로 빈도가 적었다. 그럼에 도 불구하고 언어발달과 관계가 깊게 나타난 것은 가리키기 몸짓이 었다. 이는 단순히 사물을 다른 사람에게 주는 것보다 무엇인가를 지시하거나 주의를 끌려고 손가락으로 가리키는 행동이 이후 영유 아의 언어발달을 더 유의미하게 설명하므로 가리키기 사용이 언어 능력을 촉진시키는 데 유용한 의사소통 수단임을 시사한다. 가리 키기 사용은 특히 발달장애를 조기에 선별할 수 있는 요인으로 고 려될 수도 있다. 자폐범주성장애 위험 영유아와 언어발달지체 영유 아의 몸짓 사용을 비교한 Lee 등(2014)도 16-40개월의 자폐범주성 장애 위험 영유아들이 일반 영유아 집단에 비해 유의하게 가리키 기 행동을 적게 사용하였다는 결과를 보고하여, 가리키기가 자폐 범주성장애나 언어발달 지체를 구분해주는 의사소통 몸짓이 될 수 있다고 결론을 내렸는데 이 역시 의사소통 수단으로서 가리키 기 몸짓이 갖는 중요성을 지지해주는 결과라 할 수 있다.

본 연구는 종단적 연구를 통하여 언어이전기의 의사소통 몸짓 빈도가 24 개월의 언어발달을 의미 있게 예측하여주며, 몸짓 범주 중에서는 지시적 몸짓이, 개별 몸짓 중에서는 지시하기가 이후 수 용언어와 표현언어, 표현어휘수를 모두 예측하였음을 확인하였다. 이는 선행연구를 통해서 반복적으로 보고되어 온 의사소통적 몸 짓 빈도의 예측력을 확인해주었을 뿐 아니라 어떠한 유형의 몸짓이 언어발달에 의미가 있는지를 설명하였다는 점에서 의미가 있다. 또 한 언어이전 시기에 해당하는 언어장애아 평가 시에 몸짓 사용을 다각면적으로 살펴보는 것이 이후의 언어발달을 확인할 수 있는 절 차로 활용될 수 있다는 점에서 의의를 찾을 수 있으며, 나아가서는 단순히 언어를 가르치는 데만 중점을 두기보다 몸짓을 촉진시켜주 고 확장시켜주는 것도 임상적으로 중요하게 고려해야 함을 시사한 다. 추후 연구를 통하여 지속적으로 몸짓과 언어발달 간의 관계에
대하여 종단적으로 살펴보는 연구를 통해 논의되기를 희망한다.

\section{REFERENCES}

Bates, E., \& Dick, F. (2002). Language, gesture, and the developing brain. Developmental Psychobiology, 40, 293-310.

Bates, E., Thal, D., Whitesell, K., Fenson, L., \& Oakes, L. (1989). Integrating language and gesture in infancy. Developmental Psychology, 25, 1004-1019.

Brady, N. C., Marquis, J., Fleming, K., \& McLean, L. (2004). Prelinguistic predictors of language growth in children with developmental disabilities. Journal of Speech, Language, and Hearing Research, 47, 663-677.

Butterworth, G., \& Morissette, P. (1996). Onset of pointing and the acquisition of language in infancy. Journal of Reproductive and Infant Psychology, $14,219-231$

Calandrella, A. M., \& Wilcox, M. J. (2000). Predicting language outcomes for young prelinguistic children with developmental delay. Journal of Speech, Language, and Hearing Research, 43, 1061-1071.

Camaioni, L., Castelli, M. C., Longobardi, E., \& Volterra, V. (1991). A parent report instrument for early language assessment. First Language, 11, 345358.

Capirci, O., Iverson, J. M., Pizzuto, E., \& Volterra, V. (1996). Gestures and words during the transition to two-word speech. Journal of Child language, $23,645-673$

Chang, Y. K., Choi, Y. Y., \& Kim, S. Y. (2005). The development of gesture in the early communication of Korean infants. Korean Journal of Child Studies, 26, 155-167

Crais, E., Douglas, D. D., \& Campbell, C. C. (2004). The intersection of the development of gestures and intentionality. Journal of Speech, Language, and Hearing Research, 47, 678-694.

Fenson, L., Bates, E., Dale, P. S., Hartung, J. P., Pethick, S. J., Reilly, J. S., ... \& Thal, D. J. (1996). The MacArthur communicative development inventories. San Diego, CA: Singular Publishing Gruop.

Goldin-Meadow, S., Goodrich, W., Sauer, E., \& Iverson, J. (2007). Young children use their hands to tell their mothers what to say. Developmental Science, 10, 778-785.

Harris, M., Barlow-Brown, F., \& Chasin, J. (1995). The emergence of referential understanding: pointing and the comprehension of object names. First Language, 15, 19-34.

Iverson, J. M., \& Goldin-Meadow, S. (2005). Gesture paves the way for language development. Psychological Science, 16, 367-371. 
Jang, H. S., Seo, S. J., \& Ha, J. Y. (2011). Developmental assessment for the early intervention program planning. Seoul: Hakjisa.

Jeon, J., Lee, H., \& Lee, Y. (2013). Comparison of language and social communication abilities of toddlers who are at risk of autism spectrum disorders and developmental language delay. Communication Sciences \& Disorders, 18, 349-359.

Kim, E. H., \& Kim, M. S. (2006). The relationship between the communicative gesture and the vocabulary acquisition of infants. Korean Journal of Child Studies, 27, 217-234.

Kim, Y. T., Kim, K. H., Yoon, H. R., \& Kim, H. S. (2003). Sequenced Language Scale for Infants (SELSI). Seoul: Special Education Publishing.

Lee, H. J., \& Lee, Y. (2014). Characteristics of social communication behavior in preterm toddlers. The Korean Journal of Early Childhood Special Education, 14, 105-120.

Lee, Y., \& Lee, H. (2015). Communicative gestures in toddlers with developmental language delay and their relations to language development. Communication Sciences \& Disorders, 20, 255-265.

Lee, Y., \& Lee, H. (2016). Development of intentional communicative behavior in Korean toddlers 12 to 30 months. Communication Sciences \& Disorders, $21,553-566$.

Lee, Y., \& Lee, J. (2017). Characteristics of temperament of preterm toddlers and their relation to early language and communication development. Communication Sciences \& Disorders, 22, 458-470.

Lee, Y., Jeon, J. A., \& Lee, J. Y. (2014). Communicative gestures of toddlers who are at risk autism spectrum disorder and developmental language delay. Journal of the Korean Association for Persons with Autism, 14, 17-33.
Morford, M., \& Goldin-Meadow, S. (1992). Comprehension and production of gesture in combination with speech in one-word speakers. Journal of Child Language, 19, 559-580.

Namy, L. L., Acredolo, L., \& Goodwyn, S. (2000). Verbal labels and gestural routines in parental communication with young children. Journal of Nonverbal Behavior, 24, 63-79.

Özçalıskan, S., \& Goldin-Meadow, S. (2006). X IS LIKE Y: the emergence of similarity mappings in children's early speech and gesture. Cognitive Linguistics: Current Applications and Future Perspectives, 1, 229-262.

Pae, S., \& Kwak, K. C. (2011). Korean MacArthur-Bates Communicative Development Inventories (K M-B CDI). Seoul: Mindpress.

Rowe, M. L., \& Goldin-Meadow, S. (2009). Early gesture selectively predicts later language learning. Developmental Science, 12, 182-187.

Rowe, M. L., Özçalışkan, Ş., \& Goldin-Meadow, S. (2008). Learning words by hand: gesture's role in predicting vocabulary development. First Language, 28, 182-199.

Shin, A. S., \& Kim, Y. S. (2016). Longitudinal study on vocabulary development of infants aged 10 to 18 months: centering on infants' communicative gestures and temperament. Korean Journal of Early Childhood Education, 36, 273-295.

Thal, D., Tobias, S., \& Morrison, D. (1991). Language and gesture in late talkers: a 1-year follow-up. Journal of Speech, Language, and Hearing Research, 34, 604-612.

Wetherby, A., Cain, D. H., Yonclas, D. G., \& Walker, V. G. (1988). Analysis of intentional communication of normal children from the prelinguistic to the multiword stage. Journal of Speech and Hearing Research, 31, 240-252. 
Appendix 1. Definition of gesture category

\begin{tabular}{lll}
\hline 범주 & \multicolumn{1}{c}{ 조작적 정의 } & \multicolumn{1}{c}{ 세부 몸짓 } \\
\hline 지시적 몸짓 & 사물 또는 사건을 지시하거나 또는 주의를 끌기 위한 몸짓으로 & 보여주기: 다른 사람의 시야에서 사물 제시하기 \\
& 주로 원하는 것을 표시하거나 주의를 끄는 행동 & 가리키기: 관심 있는 사물을 향해 집게 손가락으로 가리키기 \\
& 주기: 사물을 다른 사람에게 주기
\end{tabular}




\section{국문초록}

\section{언어이전 시기의 의사소통적 몸짓 사용이 24 개월 언어발달에 미치는 영향에 관한 종단연구}

\section{최진주 $\cdot$ 이윤경}

'한림대학교 대학원 언어병리청각학과, ${ }^{2}$ 한림대학교 언어청각학부

배경 및 목적: 언어이전 시기의 의사소통적 몸짓 사용은 이후 언어발달과 관련을 갖는 것으로 보고된다. 본 연구는 언어이전 시기의 몸 짓 사용이 이후 언어발달에 어떠한 영향을 미치는지 살펴보는 것을 목적으로 하였다. 방법: 연구 참가자는 K-CSBS DP 표준화 연구에 참여한 12-18개월의 영유아 중에서 24 개월의 언어발달 추적연구 참가에 동의한 42 명이었다. 언어이전기의 의사소통 몸짓은 $12-18$ 개월 사이에 수집된 CSBS DP 행동표본 중 4가지 의사소통 유도 절차와 5분의 소꿉놀이 및 책 보기 활동을 통해 얻어진 표본에서 전체 의사 소통적 몸짓 빈도, 몸짓 유형 수, 몸짓 범주별 사용 빈도, 개별 몸짓별 빈도를 측정하였다. 24개월의 언어능력은 SELSI와 K M-B CDI로 언어발달연령(수용언어연령, 표현언어연령)과 표현어휘 수로 측정하였다. 결과: 전체 몸짓 빈도, 몸짓 범주 중에서는 지시적 범주의 몸 짓 빈도가, 개별 몸짓 중에서는 손가락으로 가리키기 몸짓 빈도가 각각 수용언어연령, 표현언어연령, 표현어휘 수를 유의하게 설명하는 것으로 나타났으며, 관습적 몸짓 빈도도 수용언어연령을 유의하게 설명하는 것으로 나타났다. 논의 및 결론: 본 연구의 결과는 언어이 전기의 의사소통 몸짓 사용, 특히 몸짓 사용 빈도는 물론 지시적 범주의 몸짓과 가리키기 몸짓을 통하여 이후 24 개월의 발달을 예측할 수 있음을 확인하였다. 본 연구의 결과는 언어이전 시기의 몸짓을 다각면적으로 살펴보는 것이 이후의 언어발달을 확인 절차로 활용될 수 있다는 시사점을 갖는다.

핵심어: 영아, 의사소통적 몸짓, 몸짓 유형, 지시적 몸짓, 가리키기

본 연구는 2017년 한국언어청각임상학회 이승환장학금 지원에 의한 연구임.

\section{참고문헌}

김영태, 김경희, 윤혜련, 김화수(2003). 영유아 언어발달검사(SELSI). 서울: 도서출판 특수교육.

김의향, 김명순 (2006). 7-24개월 영아의 의사소통적 몸짓과 어휘 습득간의 관계. 아동학회지, 27, 217-234.

배소영, 곽금주(2011). 한국판 맥아더-베이츠 의사소통발달평가(K M-B CDI). 서울: 마인드프레스.

신애선, 김영실(2016). 10-18개월 영아 어휘력 발달의 종단연구: 영아의 의사소통적 몸짓과 기질을 중심으로. 유아교육연구, 36, 273-295.

이윤경, 이지영(2017). 미숙아 출생 영아의 기질 특성과 언어 및 의사소통 발달과의 관계. 언어청각장애연구, 22, 458-470.

이윤경, 이효주(2015). 언어발달지체 영아의 의사소통적 제스처 특성과 언어발달과의 관계. 언어청각장애연구, 20, 255-265.

이윤경, 이효주(2016). 12-30개월 영유아의 의도적 의사소통 행동 발달. 언어청각장애연구, 21, 553-566.

이윤경, 전진아, 이지영(2014). 자폐범주성장애 위험 영아와 언어발달지체 영아의 의사소통적 제스처 사용 비교. 자폐성장애연구, 14, 17-33.

이효주, 이윤경(2014). 미숙아출생 영유아의 사회적 의사소통 행동 특성. 유아특수교육연구, 14, 105-120.

장유경, 최윤영, 김소연(2005). 한국 영아의 초기 의사소통. 아동학회지, 26, 155-167.

장혜성, 서소정, 하지영(2011). 영아선별 교육진단검사: 전문가지침서. 서울: 학지사.

전진아, 이효주, 이윤경(2013). 자폐범주성장애 의심 영유아와 언어발달지체 영유아의 언어및 사회적 의사소통 능력 비교. 언어청각장애연구, 18 ,

349-359. 